\title{
US academics jib at Pentagon secrecy
}

Washington

Two months after unveiling the biggest research and development budget in its history, the US Department of Defense (DoD) is facing a major crisis in relations with the academic research community. The presidents of several leading research universities, believed to include Harvard, Stanford and Massachusetts Institute of Technology, have drafted a letter warning DoD that they may refuse in future to accept "sensitive" applied research contracts from the department if it implements a draft directive limiting the right of university researchers to publish.

The controversial directive, DODD 2040.2 , was the main item discussed at a meeting last week of a joint universityDoD working group looking into the impact on universities of the Reagan Administration's crackdown on the transfer of sensitive technologies to potential military adversaries. The meeting ended without agreement after the university side warned that some of the nation's best universities would withdraw from defence research altogether rather than sign contracts giving DoD the right to decide whether or not research findings should be published.

Under the directive, DoD would have no right to restrict publication of papers which emerge from contracts in research areas designated in the contract as "nonsensitive". Nor would it block publication of "sensitive" basic research papers, although it would have a chance to see them before they were submitted and ask authors to consider making changes or withholding publication. The universities' main complaint concerns papers which are both "sensitive" and "applied". In these cases, authors would have to give the papers to the Pentagon 90 days before submission to a publisher. And DoD would be allowed to insist on changes or to block publication.

DoD is already empowered to classify as secret any research findings which, if released, could seriously jeopardize the security of the United States. At last week's meeting, Gerald Lieberman, Stanford University vice-provost, said he would prefer DoD to use the formal classification procedures in such cases than to ask universities to surrender control over a wide range of research contracts. And David Wilson, the University of California political scientist chairing the university group, warned that a number of universities (he would not name them) had already signed a document saying they would refuse to accept the blanket control of "sensitive" applied projects recommended in the directive.
The universities calculate that formal classification will be used rarely, because of the strict requirements government departments must meet before proving the need for secrecy. DoD, arguing that the proposed new measures will also be saved only for rare occasions, believes it would be a pity to adopt an "all-or-nothing" approach based on classification. The two sides are to meet again to look for a compromise.

Meanwhile, the universities are facing an unexpected setback on another front in the battle against intrusive controls on research publication and dissemination. In May, pressure from the universities led to significant changes in new drafts of the expiring Export Administration Act - one of the major pieces of legislation used by the administration to staunch the flow of militarily useful information to the Soviet Union. Committees in both the Senate and the House of Representatives added language to the act asserting that it was the policy of the United States to sustain a "vigorous" scientific enterprise. "To do so," the declaration added, "requires protecting the ability of scientists and other scholars to communicate their research findings by means of publication, teaching, conferences and other means of scholarly exchange". The House of Representatives has adopted the new language, but the Senate, in voting for a package of amendments proposed by North Carolina Republican Jesse Helms, has added the word "non-sensitive" in front of the phrase "research findings". The final wording will be decided by a House-Senate conference, and in preliminary staff meetings last week there was no indication that either chamber was prepared to modify its language. The Universities, however, take comfort from the fact that Senator Helms is not a member of the conference committee.

\section{Urban research}

\section{Cambridge fights nerve gases}

Boston

THE city council of Cambridge, Massachusetts, is embroiled in another scrap with a local research institution. Three weeks ago, the city's health commissioner ordered Arthur D. Little Inc., a prominent consulting company, to cease research on toxic nerve gas and blister agents in its new high-level containment facility until an advisory committee appointed by the city manager had approved the work. A.D. Little responded by obtaining a preliminary injunction against the order of the county court two weeks ago, and the judge will rule on the company's request for a permanent injunction this week.

The controversy over the new Phillip L. Levins Laboratory began after its dedication last fall, when it was widely reported that A.D. Little had contracts from the Department of Defense to investigate ways of detecting, detoxifying and destroying highly toxic "surety agents" - chemicals whose primary use is killing people. Despite the company's protests that the containment and safety precautions far exceeded federal requirements and that the amounts of the agents to be tested were quite small, Cambridge residents living nearby were jittery.

At a tumultuous meeting in November, the city council voted to appoint a scientific advisory committee to review the proposed research. They had made little progress by February, when the Massachusetts Department of Health approved the nerve gas work, finding that the laboratory posed minimal risk to the surrounding community. Ironically, this announcement revived opposition, particularly in the neighbouring cities of Arlington and Belmont. Suspicious of the reports approving the laboratory and preferring to find out for itself, Cambridge City Council quickly requested a ninety day moratorium on work at the facility, to which the company refused to agree, citing its contractual obligations. Considerable pressure was then put on the city health commissioner, Melvin Claflin, to use his power to ban the work as a danger to public health. Despite his opinion that the laboratory was a safe facility, he issued the order prohibiting the testing, storage, transportation or disposal of nerve gas and blister agents within the city.

Left with only the option of destroying material on hand, A.D. Little argued in court that such an action would violate federal statutes that outlaw the destruction of US property, the destruction of chemical surety agents, without the permission of the Department of Defense. At the council meeting three days later, tempers flared as A.D. Little's president John Magee was denounced by a frustrated Councillor Alfred Vellucci, best known as an initiator of a ban on recombinant DNA work in Cambridge from 1975 to 1977.

This controversy could drag on in the courts for some time. Yet legal resolution of this particular issue will do little to allay public concern about the huge variety of hazardous materials in use at local universities, hospitals and corporations. Many Cambridge residents have expressed wonder at why such work - no matter how minimal the chance of a major accident has to be carried out in such a densely populated area.
Christopher Earl 